\title{
IMPLEMENTING ROTATION MODEL TO IMPROVE STUDENTS' LEARNING OUTCOMES IN SCIENCE SUBJECT AT ELEMENTARY SCHOOL
}

\author{
Roudlotul Halimi \\ Universitas Muria Kudus, Indonesia \\ roudlotulhalimi3@gmail.com
}

\begin{abstract}
The purpose of this study was to determine the effect of rotation model on students' learning outcomes at grade VI in science subject. This research used experimental research methods. The subjects in this study were 34 students at grade VI SDN Krajanbogo Bonang Demak as the experimental class and 22 students at class VIA SDN Sidomulyo 2 Wonosalam Demak as the control class. The result of N-Gain score test showed that the experimental class (applying rotation model) had an average $N$-Gain score of $66.44 \%$ which fell into 'Quite effective' category. Meanwhile, the application of the conventional model to the control class obtained an average $N$-Gain score of $39.30 \%$ in the category of 'Ineffective'. Meanwhile, the effectiveness test using the paired sample t test found that the significance value (2-tailed) was $0.000<0.05$. In addition to the significance value, the value of t count $>$ $t$ table which was 38.152> 2.035. From these results, it was concluded that the application of the rotation model gave a significant impact on students learning outcomes in science subject for grade VI elementary schools.
\end{abstract}

Keywords: rotation model, student learning outcome, science study

\section{PENERAPAN ROTATION MODEL UNTUK MENINGKATKAN HASIL BELAJAR SISWA PADA PELAJARAN IPA DI SD}

\begin{abstract}
ABSTRAK
Tujuan dari penelitian ini adalah untuk mengetahui pengaruh penerapan rotation model terhadap hasil belajar siswa kelas VI pada pelajaran IPA Penelitian ini menggunakan metode penelitian eksperimen. Subjek dalam penelitian ini adalah siswa kelas VI SDN Krajanbogo Bonang Demak dengan jumlah 34 siswa sebagai kelas eksperimen dan Kelas VI ${ }^{\mathrm{A}}$ SDN Sidomulyo 2 Wonosalam Demak dengan jumlah 22 siswa sebagai kelas kontrol. Hasil uji N-Gain score menunjukkan bahwa kelas eksperimen (dengan menerapkan rotation model) diperoleh hasil rata-rata persentase N-Gain score 66.44\% yang masuk dalam kategori 'Cukup efektif'. Sementara itu, penerapan model konvensional pada kelas kontrol diperoleh hasil rata-rata N-Gain score $39.30 \%$ dikategorikan 'Tidak efektif'. Sedangkan uji efektifan menggunakan uji paired sample t test diketahui bahwa nilai signifikansi (2-tailed) sebesar $0.000<0.05$. Selain nilai signifikansi, nilai t hitung $>$ dari t tabel yaitu 38.152 $>2.035$. Dari hasil tersebut dapat disimpulkan bahwa penerapan rotation model berdampak signifikan terhadap hasil belajar siswa pada pelajaran IPA kelas VI sekolah dasar.
\end{abstract}

Kata Kunci: rotation model, hasil belajar, IPA

\begin{tabular}{|c|c|c|}
\hline Submitted & Accepted & Published \\
\hline 03 Maret 2021 & 02 September 2021 & 16 September 2021 \\
\hline
\end{tabular}

\begin{tabular}{|l|l|c|c|}
\hline Citation & $:$ & $\begin{array}{c}\text { Halimi, R. (2021). Implementing Rotation Model to Improve Students' Learning Outcomes in Science Subject at } \\
\text { Elementary School. Jurnal PAJAR (Pendidikan dan Pengajaran), 5(5), 1306-1312. DOI : } \\
\text { http://dx.doi.org/10.33578/pjr.v5i5.8349. }\end{array}$ \\
\hline
\end{tabular}

\section{PENDAHULUAN}

Di Indonesia, pembelajaran dengan model blended learning sudah mulai marak diterapkan, akan tetapi masih sulit sekali menemukan hasil penelitian yang mengkaji tentang penerapannya untuk sekolah dasar. Pembelajaran dengan model blended learning tidak hanya menerapkan model pembelajaran online saja, namun mengintegrasikan dengan pembelajaran tatap muka. Salah satu tipe model blended learning adalah rotation model. Rotation model ini dapat digunakan untuk saling melengkapi kekurangan yang ada pada pembelajaran konvensional dan pembelajaran online. Kondisi pandemi covid-19 saat ini dapat dijadikan momentum yang tepat untuk guru agar berkreasi dan berinovasi dalam menerapkan model pembelajaran. Model pembelajaran yang tepat dan efektif salah satunya adalah model blended learning tipe rotasi atau rotation model.

Di masa pandemi inilah, guru mencoba untuk beralih dari pembelajaran tatap muka menjadi pembalajaran dalam jaringan (daring). 
Ada beberapa prasyarat bagi guru dalam proses pembelajaran daring yaitu ketersediannya handphone, kuota dan jaringan internet yang stabil. Faktor penghambat atau yang menjadi kendala pelaksanaan pembelajaran daring diantaranya adalah belum semua peserta didik memiliki handphone dan masih banyak orang tua sibuk bekerja (Putria. 2020). Kelemahan lain dari pembelajaran daring adalah kurangnya pengawasan siswa selama proses pembelajaran daring (Sadikin, A., \& Hamidah, A, 2020). Dengan minim interaksi dan pengawasan inilah, hasil pembelajaran yang didapat menjadi kurang maksimal.

Pembelajaran dengan rotation model bisa menjadi alternatif pengganti pembelajaran tatap muka yang memang masih belum bisa dilaksanaan secara penuh pada masa pandemi ini. Seiring dengan berkembangnya teknologi di dunia pendidikan yang sangat pesat, model pembelajaran rotation model dapat dilakukan untuk melengkapi kekurangan pada pembelajaran tatap muka dan pembelajaran online. Mengaitkan antara pembelajaran dengan perkembangan teknologi bukanlah hal yang mudah. Penggunaan teknologi dalam proses pembelajaran tentunya tidak boleh meninggalkan esensi dari pembelajaran itu sendiri. Menurut Pane \& Darwis Dasopang (2017) proses pembelajaran adalah "suatu sistem yang melibatkan satu kesatuan komponen yang saling berkaitan dan saling berinteraksi untuk mencapai suatu hasil yang diharapkan secara optimal sesuai dengan tujuan yang telah ditetapkan". Dari pendapat di atas jelas bahwa pembelajaran adalah sebuah sistem yang saling berkaitan dan tidak terpisah.

Dalam sebuah pembelajaran, sangat penting untuk membuat pembelajaran yang berpusat pada siswa. Selain itu, realita di lapangan menunjukkan hasil belajar siswa SD dalam pembelajaran IPA masih rendah. Hal ini salah satunya disebabkan selama ini digunakan model pembelajaran yang konvensional (berpusat pada guru) sehingga tidak terbentuk pembelajaran yang PAKEM (Aktif, kreatif, efektif, dan menyenangkan. Oleh sebab itulah, diperlukan usaha meningkatkan hasil belajar siswa dalam pelajaran IPA dengan menggunakan model blended learning tipe rotasi atau rotation model.

\section{KAJIAN TEORETIS}

Prayitno (2015) menyatakan bahwa rotation model yang termasuk dalam blended learning merupakan proses pembelajaran yang memanfaatkan berbagai macam pendekatan yang memanfaatkan berbagai macam media dan teknologi. Pembelajaran dengan rotation model memiliki tiga tahapan dasar atau sintaks dalam penerapannya (Ramsay, 2001). Ketiga sintaks tersebut adalah (1) Seeking information; Mencakup pencarian informasi dari berbagai sumber informasi yang tersedia secara online maupun offline dengan berdasarkan pada relevansi, validitas, reliabilitas konten dan kejelasan akademis. Guru berperan memberi masukan bagi siswa untuk mencari informasi yang efektif dan efisien. (2) Acquisition of information; Siswa secara individu maupun secara kelompok kooperatif-kolaboratif berupaya untuk menemukan, memahami, serta mengkonfrontasikannya dengan ide atau gagasan yang telah ada dalam pikiran siswa, kemudian menginterprestasikan informasi/pengetahuan dari berbagai sumber yang tersedia, sampai mereka mampu mengkomunikasikan kembali dan menginterpretasikan ide-ide dan hasil interprestasinya menggunakan fasilitas dan (3) synthesizing of knolegde. Mengkonstruksi /merekonstruksi pengetahuan melalui proses asimilasi dan akomodasi bertolak dari hasil analisis, diskusi dan perumusan kesimpulan dari informasi yang diperoleh.

Sementara itu, Sugihartono (2007), menyebutkan faktor-faktor yang mempengaruhi hasil belajar, antara lain 1) Faktor internal adalah faktor yang ada dalam diri individu yang sedang belajar. Faktor internal meliputi: faktor jasmaniah dan faktor psikologis. 2) Faktor eksternal adalah faktor yang ada di luar individu. Faktor eksternal meliputi: faktor keluarga, faktor sekolah, dan faktor masyarakat. Dalam penelitian ini, penerapan rotation model diharapkan dapat meningkatkan hasil belajar siswa khususnya pada pelajaran IPA. 
Sebuah penelitian yang dilakukan oleh Agus Purnomo, Nurul Ratnawati, dan Nevy Farista Aristin (2017) menyatakan bahwa mengkombinasikan pembelajaran konvensional dengan media komunikasi seperti whatsapp dan google drive merupakan salah satu solusi mudah pembelajaran pada generasi-z. Siswa yang terbiasa berkomunikasi menggunakan jejaring sosial dapat mengakses materi dan rencana pembelajaran yang sudah disusun dengan terstruktur setiap pertemuan. Sehingga mereka dapat membaca atau menyiapkan pertanyaan sebelum pembelajaran dimulai. Hasil penelitian tersebut dapat menjadi pemicu guru untuk berinovasi terhadap model pembelajaran rotation model guna meningkatkan kualitas proses pembelajaran maupun hasil pembelajaran.

\section{METODE PENELITIAN}

Pendekatan penelitian yang digunakan adalah kuantitatif. Pendekatan kuantitatif merupakan penelitian yang data-datanya berupa angka-angka dan analisis menggunakan statistik (Sugiyono:2015). Penelitian ini menggunakan metode penelitian eksperimen. Penelitian eksperimen adalah penelitian yang menguji hubungan sebab akibat. Jenis penelitian ini adalah true eksperimen dengan desain pretest postest control group design.

\section{Sumber data}

Menurut Sugiyono (2015) populasi adalah obyek atau subyek yang memiliki kualitas dan karakteristik tertentu dalam wilayah generalisasi, diterapkan untuk dipelajari dan kemudian dismpulkan oleh peneliti. Dalam penelitian ini populasinya adalah seluruh sekolah dasar Kabupaten Demak berjumlah 476 Sekolah Dasar Negeri dan 147 Sekolah Dasar Swasta. Menurut Sugiyono (2015), sampel ialah populasi yang memiliki bagian dari jumlah dan karakteristik. Sampel dalam penelitian ini berjumalah 34 siswa dari SDN Krajanbogo Kecamatan Bonang Kabupaten Demak dan 22 siswa dari SDN Sidomulyo 2 Kecamatan Wonosalam Kabupaten Demak.

\section{Tekhnik pengumpulan}

a. Tes, Tes berupa pilihan ganda berjumlah 30 soal,

b. Observasi/pengamatan, instrumen Observasi berupa lembar pengamatan berjumlah 20 instrumen

c. Dokumentasi, dokumentasi (foto kegiatan, daftar hadir, jurnal harian, daftar nilai)

\section{Tekhnik Analisis Tes \\ Uji instrumen \\ Uji Validitas}

Dalam penelitian ini terdiri atas uji validitas, reabilitas, taraf kesukaran, dan daya pembeda. Adapun ringkasan hasil validitas butir soal adalah sebagai berikut:

Tabel 1. Rekap Hasil Analisis Validitas Soal

\begin{tabular}{lcl}
\hline \multicolumn{1}{c}{ Kriteria } & Jumlah & \multicolumn{1}{c}{ Nomor Butir Pertanyaan } \\
\hline Tidak & 0 & - \\
Valid & & $1,2,3,4,5,6,7,8,9,10,11,12,13,14,15,16,17,18,19,20$, \\
\hline Valid & 30 & $21,22,23,24,25,26,27,28,29,30$ \\
& &
\end{tabular}

Sumber: Hasil pengolahan data SPSS 23

Dari tabel di atas dapat dilihat bahwa seluruh soal tes yang akan digunakan untuk mengukur efektifitas hasil belajar siswa sudah valid seluruhnya. Dengan demikian, soal yang sudah dibuat dan valid dapat digunakan sebagai soal penilaian.

\section{Uji Reliabilitas}

Uji reliabilitas dalam penelitian diperoleh hasil sebagai berikut: 
Tabel 2. Hasil Uji Reliabilitas Soal

\begin{tabular}{ll}
\hline $\begin{array}{l}\text { Hasil Uji Reliabilitas } \\
\text { (Guttman Split-Half Coefficient) }\end{array}$ & Kategori \\
\hline 0,867 & Tinggi \\
\hline Sumber: Hasil pengolahan data SPSS 23 & \\
Dari tabel di atas menunjukkan bahwa & Uji Taraf Kesukaran \\
reliabilitas statistik dari Guttman Split-Half & Adapun hasil uji taraf kesukaran yaitu \\
an demient yang didapatkan sebesar 0.867. & sebagai berikut:
\end{tabular}
instrumen dengan tipe soal pilihan ganda ini adalah reliabel karena sudah melebihi nilai patokan 0.6

Tabel 3. Rekap Hasil Analisis Uji Taraf Kesukaran Soal

\begin{tabular}{clll}
\hline No & Kriteria & Item Butir Soal & Jumlah \\
\hline \multirow{2}{*}{1} & Mudah & $\begin{array}{l}1,4,6,7,8,10,15,16,17,18,19,20,21,23, \\
25,27,28,29\end{array}$ & 18 item soal \\
\hline 2 & Sedang & $3,5,9,11,12,22,24,26,30$ & 9 item soal \\
\hline 3 & Sukar & $2,13,14$ & 3 item soal \\
\hline
\end{tabular}

Sumber: Hasil pengolahan data SPSS 23

Berdasarkan hasil analisis uji taraf kesukaran diperoleh 18 item soal yang tergolong mudah, 9 item soal yang tergolong sedang, dan 3 item soal yang tergolong sukar.

\section{Uji Daya Beda}

Berdasarkan perhitungan daya pembeda diperoleh hasil sebagai berikut:

Tabel 4. Rekap Hasil Uji Daya Beda Soal

\begin{tabular}{lllc}
\hline No & Kriteria & Nomor Soal & Jumlah \\
\hline 1 & Jelek & - & 0 \\
\hline 2 & Cukup & - & 0 \\
\hline 3 & Baik & $1,2,3,4,5,6,7,8,9,10,11,12,13,14,15,16$, & 30 \\
& $17,18,19,20,21,22,23,24,25,26,27,28,29$, \\
\\
$\quad 30$ & 00 \\
\hline 4 & Baik sekali & - &
\end{tabular}

Dari hasil perhitungan tabel di atas diketahui bahwa seluruh soal memiliki daya pembeda yang tergolong dalam kategori baik karena nilai berada di atas kisaran 0,41 .

\section{HASIL DAN PEMBAHASAN}

Pada penelitian ini kelas eksperimen menggunakan pembelajaran dengan rotation model. Eksperimen ini dilaksanakan pada kelas VI SDN Krajanbogo Kecamatan Bonang Kabupaten Demak. Siswa dalam eksperimen ini berjumlah 34 siswa. Setelah dilaksanakan post test, diperoleh sebaran nilai dari 30 soal pilihan ganda. Hasil sebaran ini diadakan analisis deskriptif yaitu analisis menggunakan metode statistik dengan tujuan memperoleh pola sejumlah penelitian, merangkumnya, dan terus menyajikan informasi sesuai bentuk yang diinginkan.

1. Daftar Distribusi Frekuensi berikut: 
Jurnal PAJAR (Pendidikan dan Pengajaran)

Volume 5 Nomor 5 September 2021 | ISSN Cetak : 2580 - 8435| ISSN Online : 2614 - 1337

DOI : http://dx.doi.org/10.33578/pjr.v5i5.8349

Tabel 5. Hasil Nilai Post Test Kelas Eksperimen dengan Rotation Model

\begin{tabular}{ccccc}
\hline No. & Nilai & Tabulasi & Frekuensi & Nilai x frekuensi \\
\hline 1 & 63 & $/ /$ & 2 & 126 \\
\hline 2 & 67 & $/$ & 1 & 67 \\
\hline 3 & 70 & $/ I / /$ & 4 & 280 \\
\hline 4 & 73 & $/ I / /$ & 4 & 77 \\
\hline 5 & 77 & $/$ & 1 & 400 \\
\hline 6 & 80 & $/ I / /$ & 5 & 415 \\
\hline 7 & 83 & $/ I / /$ & 5 & 522 \\
\hline 8 & 87 & $/ / I / /$ & 6 & 180 \\
\hline 9 & 90 & $/ /$ & 2 & 372 \\
\hline 10 & 93 & $/ I / /$ & 4 & 2731 \\
\hline
\end{tabular}

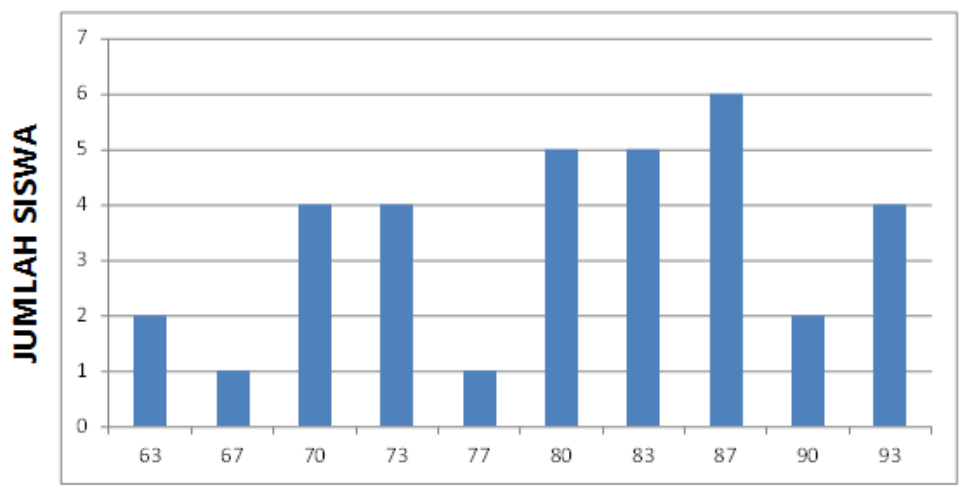

NILAI SISWA

Gambar 1. Diagram Nilai Eksperimen

2. Mean, Median, dan Modus

Dari analisis data post test kelas eksperimen diperoleh hasil median sebesar 81.5 dan modus atau nilai terbanyak yaitu 87

3. Ketuntasan Belajar

KKM muatan pelajaran IPA 70, berarti siswa yang memperoleh nilai lebih atau minimal 70 sebanyak 31 siswa. Sebanyak 3 siswa mendapat nilai di bawah 70 . Hal ini menunjukkan bahwa 91\% siswa siswa kelas VI SDN Krajanbogo Kecamatan Bonang (kelas eksperimen) telah mencapai batas KKM. Sisanya sebanyak $9 \%$ siswa belum tuntas belajar.

\section{Uji N-Gain Score}

Dari hasil perhitungan uji $\mathrm{N}$-gain score tersebut, menunjukkan bahwa nilai rata-rata $N$ gain score untuk kelas eksperimen (rotation model) adalah sebesar 71.8796 atau $71,88 \%$. Sementara itu, untuk rata-rata $\mathrm{N}$-gain score untuk kelas kontrol (metode konvensional) adalah sebesar 39.3037 atau $39.30 \%$. Untuk melihat keefektifan dari penerapan rotation model tersebut kemudian nilai rata persentase $N$-gain score diklasifikasikan sesuai pengkategoriannya. 
Jurnal PAJAR (Pendidikan dan Pengajaran)

Volume 5 Nomor 5 September 2021 | ISSN Cetak : 2580 - 8435 | ISSN Online : 2614 - 1337

DOI : http://dx.doi.org/10.33578/pjr.v5i5.8349

Tabel 6. Rekap Hasil Uji N-Gain score Kelas Eksperimen dan Kelas Kontrol

\begin{tabular}{|c|c|c|c|}
\hline No & Kelas & $\begin{array}{l}\text { Rata-rata } N \text {-Gain } \\
\text { score }(\%)\end{array}$ & Keterangan \\
\hline 1 & $\begin{array}{l}\text { Eksperimen (menggunakan rotation } \\
\text { model) }\end{array}$ & 66.44 & $\begin{array}{l}\text { Cukup } \\
\text { Efektif }\end{array}$ \\
\hline 2 & $\begin{array}{l}\text { Kontrol } \\
\text { (metode konvensional) }\end{array}$ & 39.30 & Tidak Efektif \\
\hline
\end{tabular}

Sumber: Hasil pengolahan data SPSS 23

Dari tabel di atas dapat disimpulkan bahwa penerapan rotation model di kelas eksperimen (pembelajaran dengan rotation model) diperoleh hasil rata-rata $\mathrm{N}$-gain score 66.44 atau $66.44 \%$ dikategorikan 'Cukup efektif'. Sementara itu, penerapan model konvensional pada kelas kontrol diperoleh hasil rata-rata $N$-Gain score 39.30 atau $39.30 \%$ dikategorikan 'Tidak efektif'.

Analisis uji keefektifan menggunakan uji $\mathrm{t}$ terhadap hasil belajar siswa pada sekolah yang menerapkan rotation model dengan sekolah yang tidak menerapkan rotation model dengan hipotesis sebagai berikut.

Ha : $\quad$ Terdapat perbedaan yang signifikan antara pembelajaran yang menerapkan dan yang tidak menerapkan rotation model.
Ho : $\quad$ Tidak terdapat perbedaan yang signifikan antara pembelajaran yang menerapkan dan yang tidak menerapkan rotation model.

Kriteria pengujian yang digunakan adalah apabila nilai signifikansi $<0.05$ maka Ha diterima dan Ho ditolak. Nilai signifikansi > 0.05 maka Ha ditolak dan Ho diterima. Selain menggunakan nilai signifikansi, juga digunakan perbandingan antara nilai $t$ hitung dan $t$ tabel. Apabila nilai $t$ hitung $>t$ tabel maka Ha diterima dan Ho ditolak. Apabila nilai $\mathrm{t}$ hitung $<\mathrm{t}$ tabel maka Ha ditolak dan Ho diterima. Hasil analisis data uji keefektifan penerapan rotation model dalam pembelajaran IPA dapat disajikan dalam tabel berikut.

Tabel 7. Hasil Uji paired sample t test

\begin{tabular}{|c|c|c|c|c|c|c|c|c|c|}
\hline & & \multicolumn{5}{|c|}{ Paired Differences } & \multirow{3}{*}{$\mathrm{t}$} & \multirow{3}{*}{ df } & \multirow{3}{*}{$\begin{array}{l}\text { Sig. (2- } \\
\text { tailed) }\end{array}$} \\
\hline & & \multirow[t]{2}{*}{ Mean } & \multirow[t]{2}{*}{$\begin{array}{l}\text { Std. } \\
\text { Deviation }\end{array}$} & \multirow[t]{2}{*}{$\begin{array}{l}\text { Std. } \\
\text { Error } \\
\text { Mean }\end{array}$} & \multicolumn{2}{|c|}{$\begin{array}{l}95 \% \text { Confidence } \\
\text { Interval of the } \\
\text { Difference }\end{array}$} & & & \\
\hline & & & & & Lower & Upper & & & \\
\hline Pair 1 & $\begin{array}{l}\text { Pre Test Kls } \\
\text { Eksperimen - Post } \\
\text { Test Kls } \\
\text { Eksperimen }\end{array}$ & 37.029 & 5.659 & .971 & 35.055 & 39.004 & 38.152 & 33 & .000 \\
\hline
\end{tabular}

Berdasarkan hasil analisis uji $\mathrm{t}$ diperoleh hasil bahwa nilai signifikansi kedua sekolah eksperimen adalah sebesar 0.000. Nilai signifikansi ini kurang dari 0.005. Dengan demikian hasil uji t dengan paired sample $t$ test menunjukkan nilai signifikansi $0.000<0.005$. Mengacu pada kriteria pengujian bahwa apabila nilai signifikansi $<0.05$ maka Ha diterima dan Ho ditolak. Hal ini berarti bahwa Ha pada penelitian ini diterima dan Ho ditolak. Sementara itu, t hitung pada penelitian ini diperoleh nilai sebesar 38.152. Selanjutnya, nilai t tabel dicari berdasarkan nilai df (degree of freedom atau derajat kebebasan). Nilai df dari tabel dapat dilihat sebesar 33 sehingga nilai $\mathrm{t}$ tabel sebesar 2.035. Dengan demikian diperoleh nilai $\mathrm{t}$ hitung $>\mathrm{t}$ tabel yaitu $38.152>2.035$. Dari hasil tersebut dapat disimpulkan bahwa terdapat perbedaan yang signifikan antara pembelajaran 
yang menerapkan dan yang tidak menerapkan rotation model.

\section{SIMPULAN DAN REKOMENDASI}

Kesimpulan dari penelitian ini adalah keefektifan model pembelajaran blended learning ini dapat dilihat dari hasil uji $\mathrm{N}$-Gain score yang hasilnya adalah kelas eksperimen (dengan menerapkan rotation model) diperoleh hasil ratarata persentase $N$-Gain score $66.44 \%$ dikategorikan 'Cukup efektif'. Sementara itu, penerapan model konvensional pada kelas kontrol diperoleh hasil rata-rata $N$-Gain score $39.30 \%$ dikategorikan 'Tidak efektif'. Sedangkan uji efektifan menggunakan uji paired sample $t$ test diketahui bahwa nilai signifikansi (2-tailed) sebesar $0.000<0.05$. Hasil t hitung pada kelas eksperimen juga menunjukkan nilai yang lebih besar dari $\mathrm{t}$ tabel yaitu $38.152>2.035$. Hasil tersebut menunjukkan bahwa Ha diterima dan Ho ditolak yang berarti terdapat perbedaan yang nyata antara hasil belajar siswa pada pre test dan post test. Sehingga dari hasil tersebut dapat disimpulkan bahwa penerapan rotation model berdampak signifikan terhadap hasil belajar siswa pada pelajaran IPA kelas VI sekolah dasar.

Rekomendasi yang perlu dipertimbangkan adalah Pembelajaran hendaknya dilaksanakan dengan mempertimbangkan ketercapaian tujuan pembelajaran, kesiapan guru dan siswa sehingga dampak instruksional dalam pengembangan model pembelajaran ini dapat berhasil dalam segi kualitas proses dan hasil pembelajaran. Selain itu, Pelaksanaan model pembelajaran hendaknya disesuaikan dengan kebutuhan guru dan siswa agar tujuan pembelajaran dapat tercapai lebih optimal.

\section{UCAPAN TERIMA KASIH}

Ucapakan terima kasih ditujukan kepada keluarga besar Universitas Muria Kudus, SDS Nurul Huda Desa Katonsari Demak, dan SDN Sidomulyo Wonosalam Demak yang telah memberikan ijin untuk melakukan penelitian. Terima kasih juga kepada semua pihak yang telah membantu dalam penelitian ini. Semoga Allah meridhoi dan menerima amal kebaikan kita.

\section{DAFTAR PUSTAKA}

Grant, R. (2001). Teaching and Learning With Information and Communication Technology: Succes Through a Whole School

Pane, A., \& Darwis Dasopang, M. (2017). Belajar Dan Pembelajaran. Jurnal Kajian IlmuIlmu Keislaman, 3(2), 333-352.

Prayitno, W. (2015). Implementasi Blended learning Dalam Pembelajaran Pada Pendidikan Dasar dan Menengah. Jurnal Pendidikan, 6(01).

Purnomo, Agus; Ratnawati, Nurul; Aristin, Nevy Farista. (2017). Pengembangan Pembelajaran Blended learning Pada Generasi Z. Jurnal Teori dan Praksis Pembelajaran IPS, 1(1), 70-76.

Putria, H., Maula, L. H., \& Uswatun, D. A. (2020). Analisis proses pembelajaran dalam jaringan (daring) masa pandemi covid-19 pada guru sekolah dasar. Jurnal Basicedu, 4(4), 861-870.

Sadikin, A., \& Hamidah, A. (2020). Pembelajaran Daring di Tengah Wabah Covid19:(Online Learning in the Middle of the Covid-19 Pandemic). Biodik, 6(2), 214224.

Sugihartono, dkk. (2007). Psikologi pendidikan. Yogyakarta: UNY Press

Sugiyono. (2015). Metode penelitian Pendidikan (Pendekatan Kualitatif, Kuantitatif, dan $R$ and $D)$. Persada, Grafindo.

Usman, U. (2019). Komunikasi Pendidikan Berbasis Blended learning Dalam Membentuk Kemandirian Belajar. Jurnal Jurnalisa, 4(1), 136-150.

Wahyudi, W., Anugraheni, I., \& Winanto, A. (2018). Pengembangan Rotation model Berbasis Proyek Untuk Menunjang Kreatifitas Mahasiswa Merancang Pembelajaran Matematika Sekolah Dasar. JIPM (Jurnal Ilmiah Pendidikan Matematika), 6(2), 68-81

Widyaningsih, Octaviany. (2019). Pengembangan Model Pembelajaran Blended learning Untuk Sekolah Dasar. Jurnal Pendidikan Dasar, 10(2), 143-156. 